\title{
Uncorrected Tetralogy of Fallot in a 51-Year-Old Patient
}

Fatih Koç, Özgür Günebakmaz, Ali Doğan, Orhan Doğdu, Mehmet Güngör Kaya

Erciyes University, School of Medicine, Department of Cardiology, Kayseri, Turkey Eur J Gen Med 2010;7(3):330-332

Received: 25.09 .2009

Accepted: 16.12.2009

Correspondence: Fatih Koc, Erciyes University School of Medicine Department of Cardiology, 38039 Kayseri, Turkey

Tel: $903524374937 / 27792$

Fax: 903524376198

E-mail:drfatkoc@gmail.com

\begin{abstract}
Tetralogy of Fallot (TOF) is the most common cyanotic congenital heart disease. This report describes the case of a fifty-one year old man who presents with an exertional dyspnea and polycythemia. Echocardiography showed perimembranous ventricular septal defect, hypertrophy of the right ventricle, over-riding of the aorta and stenosis of the right ventricular outflow tract.
\end{abstract}

Key words: Tetralogy of Fallot, uncorrected, polycytemia

\section{Düzeltilmemiş 51 Yaşında Fallot Tetralojisi}

Fallot tetralojisi en yaygın siyanotik konjenital kalp hastalığıdır. Bu rapor 51 yașında efor dispnesi ve polisitemia ile bașvuran 51 yașında erkek hasta ile ilgilidir. Ekokardiyografi ile perimembranöz ventriküler septal defekt, sağ ventrikül hipertrofisi, ata biner șekilli aorta ve sağ ventrikül çıkış yolunda daralma izlendi.

Anahtar kelimeler: Fallot tetralojisi, düzeltilmemiș, polisitemia

\section{INTRODUCTION}

Tetralogy of Fallot (TOF) is the most common cyanotic congenital heart disease, with $10 \%$ of all congenital heart malformations (1). Tetralogy of Fallot includes four major component which are ventricular septal defect (VSD), overriding aorta, right ventricle outflow tract obstruction and right vetricle hypertrophy (RVH) (2). At the present time, the most of these patients are diagnosed in first year of their life's and moreover the majority of these patients are diagnosed in antenatal period, however this disorder may be occasionally recognized at adulthood $(1,3)$. Echocardiography is an indispensable method for organizing treatment 


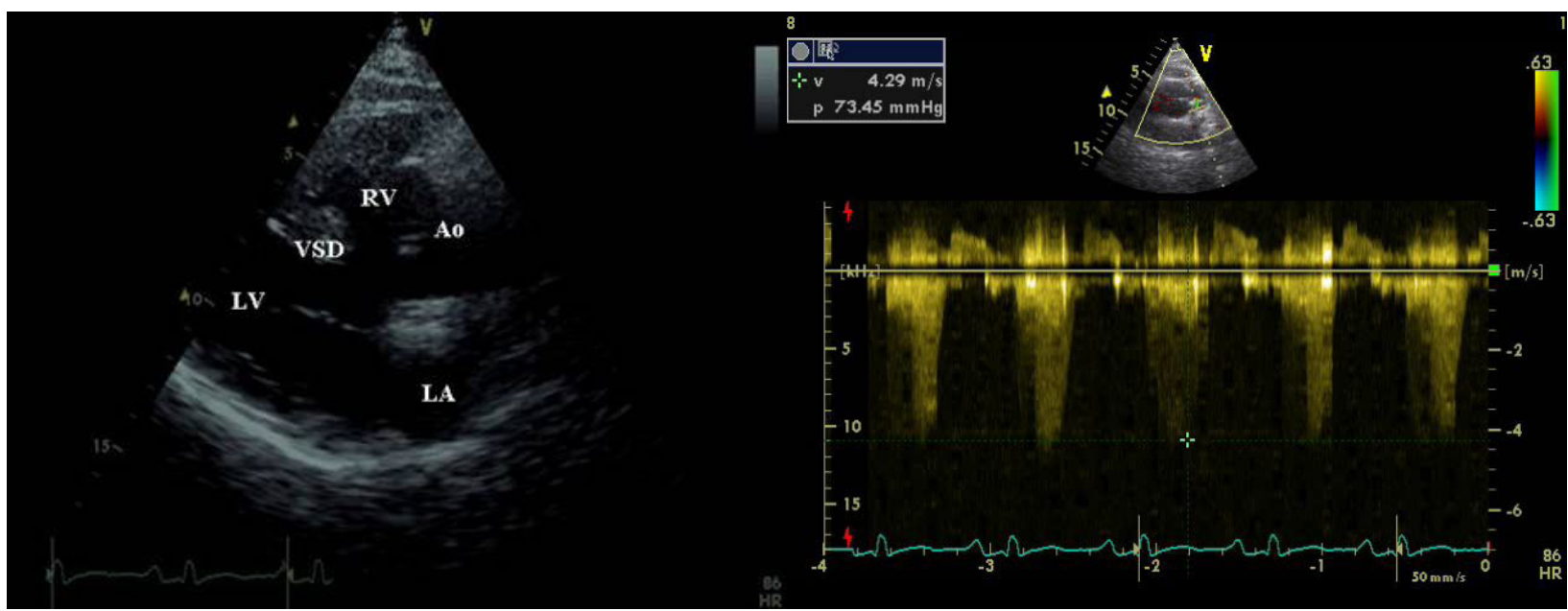

Figure 1. Tetralogy of Fallot in parasternal long axis VieW (Ao: Aorta, LA: Left atrium, LV: Left ventricle, RV: Right ventricle, VSD: Ventricular septal defect)
Figure 2. Stenosis of the right ventricular outflow tract and diagnosis of the disease (3). Despite of the fact that TOF is a fatal disease particularly when not being treated, approximately $85 \%$ of the patients are able to survive up to adulthood after surgical correction (4).

We have reported a TOF patient who was not diagnosed and was not treated up to 51 years old.

\section{CASE}

A fifty-one year old man was referred to the hematology department of our university due to his polycythemia. On his medical history, he had mild to moderate exertional dyspnea for approximately ten years and phlebotomy had been performed several times.

Initial clinical assessment designated a well nourished individual with central cyanosis. His blood pressure was $110 / 80 \mathrm{mmHg}$, pulse 92 beats per minute and respiratory rate of 18 breaths per minute. His oxygen saturation was $68 \%$ under room air. Auscultation exposed a loud first heart sound with systolic ejection murmur at the left sternal border. The lungs were clear. Electrocardiogram (ECG) showed sinus rhythm with RVH and right bundle branch block (RBBB). Polycythemia was detected by hemoglobin of $21.4 \mathrm{~g} / \mathrm{dl}$ and hematocrit of $61.1 \%$.

The transthorasic echocardiography was applied. Perimembranous ventricular septal defect (Figure 1), hypertrophy of the right ventricle, over-riding of the aorta and valvular stenosis of the right ventricular outflow tract with a pressure gradient of $73 \mathrm{mmHg}$ were obtained (Figure 2). Left ventricular dimension and functions was normal. Operation couldn't have been performed because of the patient's refuse.

\section{DISCUSSION}

Tetralogy of Fallot is generally presented with cyanosis at childhood whereas dyspne, exercise intolerance and cyanosis are mainly occurred at adulthood (5). The cause of cyanosis seen in earlier time is the shunt being from right to left. The shunt becomes from left to right in some patient when resistance of right ventricular outflow tract is lower than left system and thus cyanosis will not be seen and the patient will be diagnosed in a later period consequently (1). It was shown in the previous studies that surgical total correction in an earlier period is the best treatment option. The most patients not being treated are to die probably at childhood (1). Pulmonary hemorrhagia, brain abscess and thromboembolic complications are the most prominent causes of death (4). Only $1 \%$ of the patients not being treated can survive up to 50 years old. However the survival rate for those being operated is about $74 \%(2,5)$. The oldest 
uncorrected TOF in the literature aged 86 was reported from USA (6). In our country, the oldest uncorrected TOF reported by Yokusoglu et al. was 68 years old (2).

In conclusion, our patient was asymptomatic for a long time and the diagnosis were made while polycythemia was being investigated. Even though there are some TFO cases diagnosed at older age in litterateur, this case among the others reported in our country is one of the oldest patients not being diagnosed $(1,5,7)$.

\section{REFERENCES}

1. Semeraro $O$, Scott B, Vermeersch P. Surgical correction of tetralogy of Fallot in a seventy-five year old patient. Int J Cardiol 2008;128:98-100.

2. Yokuşoğlu M, Köz C, Baysan O, Bariș N. Unoperated tetralogy of Fallot in a 68-year-old patient. Turk Kardiyol Dern Ars 2008;36: 175-7.
3. Bailliard F, Anderson RH. Tetralogy of Fallot. Orphanet $J$ Rare Dis 2009;4: 2.

4. Mizia-Stec K, Gasior Z, Haberka M, Oleś R, Adamczyk T. Adult patient after correction of tetralogy of Fallotdiagnostic and therapeutic issues. Pol Arch Med Wewn 2007;117: 38-43.

5. Fairley SL, Sands AJ, Wilson CM. Uncorrected tetralogy of Fallot: adult presentation in the 61st year of life. Int J Cardiol 2008;128:9-11.

6. Alonso A, Downey BC, Kuvin JT. Uncorrected tetralogy of Fallot in an 86-year-old patient. Am J Geriatr Cardiol 2007; 16:38-41.

7. Shaff DA, Raines DE, Vidal Melo MF, King ME, Misra S, Chen LL. Anesthetic management for transurethral resection of the bladder in a 74-year-old man with uncorrected tetralogy of Fallot. J Clin Anesth 2005;17:198-201. 